\title{
Field Evaluation of Twelve Clones of Oregano Grown in the Main Production Areas of Argentina: Identification of Quantitative Trait with the Highest Discriminant Value
}

\author{
Lorena E. Torres, ${ }^{1}$ Paula C. Brunetti, ${ }^{1}$ Carla Baglio, ${ }^{2}$ Pablo G. Bauzá, ${ }^{2}$ Ana G. Chaves, \\ Yamile Massuh, ${ }^{1}$ Sonia F. Ocaño, ${ }^{1}$ and Marta S. Ojeda ${ }^{1}$ \\ ${ }^{1}$ Cátedra de Genética, Facultad de Ciencias Agropecuarias, Universidad Nacional de Córdoba, Avenida Valparaíso s/n, \\ Ciudad Universitaria, CC 509, 5000 Córdoba, Argentina \\ ${ }^{2}$ EEA La Consulta, INTA, Ex Ruta $40 \mathrm{~km}$ 96, La Consulta, San Carlos, Mendoza, Argentina
}

Correspondence should be addressed to Lorena E. Torres, lorenatorres@agro.unc.edu.ar

Received 24 April 2012; Accepted 28 May 2012

Academic Editors: O. Ferrarese-Filho and I. Vasilakoglou

Copyright (C) 2012 Lorena E. Torres et al. This is an open access article distributed under the Creative Commons Attribution License, which permits unrestricted use, distribution, and reproduction in any medium, provided the original work is properly cited.

\begin{abstract}
In Argentina, oregano (Origanum spp.) is one of the most important aromatic species. Leaves and flowering tops are used as seasoning, targeting the retail consumer, industrial and less to export. Local production has low-average yields due to the variability of cultivated material, the vegetative propagation methods used, and the lack of knowledge and adaptive experimentation on advanced cultivation practices. Clones of oregano grown in the country were collected in order to characterize the germplasm used in Argentina. Twelve oregano clones, sanitized by meristems culture and micropropagated in vitro, were field evaluated in three different growing locations. Regardless of growing site, the quantitative variables with more discriminating value were essential oils yield, internode length, length of the longest branch, fresh weight, dry weight of leaf and stem, leaf/stem ratio, and leaf area. Based on the quantitative traits, oregano clones can be classified into four groups. From the observations based on botanical characteristics, it was determined that the evaluated clones belong to three different taxa: Origanum vulgare ssp. vulgare, Origanum vulgare ssp. hirtum, and Origanum $x$ majoricum (hybrid). Within each group, the clones belong to the same taxon.
\end{abstract}

\section{Introduction}

The genus Origanum belongs to the family Lamiaceae and includes more than 70 species, subspecies, varieties, and hybrids that are commonly found as wild plants in the Mediterranean areas [1]. This aromatic herb, mainly used as condiment, in liquors formulations, tomato sauces, baked goods, and salad dressing [2-10], is one of the most important aromatic spices cultivated in Argentina from the point of view of demand and acreage (80\%) [11]. The main production areas are located in the provinces of Mendoza, Córdoba, and San Juan [12] although there are smaller production areas in the northwestern regions of the provinces of Salta and Jujuy [10]. The local production of oregano is mainly for domestic consumption; however, in recent years a surplus production for export was registered.
Despite this surplus production, the cultivation of oregano in our country is still affected by several problems. The oregano produced often does not have the best qualities to be considered a premium product for food because it is grown regardless of the variety, health, and the harvest and postharvest practices; in this situation, it is not possible to conserve a product free of contamination. Besides there is little taxonomic identification of the plant material used for cultivation; in fact, in our country registered cultivars and/or varieties of oregano do not exist [12], and the fantasy names used to designate the different materials are local names assigned by the producers, who include in those names phenotypic characteristics of the material or its place of origin [13]; even more, those fantasy names are often given to materials that are genetically equivalent [10]. 
TABLE 1: Twelve clones of oregano collected from the main production areas of Argentina.

\begin{tabular}{ll}
\hline Provenance & Germplasm \\
\hline \multirow{3}{*}{ Mendoza } & Criollo $(\mathrm{Cr}-\mathrm{Mza})$ \\
& Compacto $(\mathrm{Cm}-\mathrm{Mza})$ \\
& Mendocino $(\mathrm{Me}-\mathrm{Mza})$ \\
& Cordobés $(\mathrm{Cd}-\mathrm{Mza})$ \\
\hline & Clon $1\left(\mathrm{C}_{1}-\mathrm{FCA}\right)$ \\
& Clon $2\left(\mathrm{C}_{2}-\mathrm{FCA}\right)$ \\
& Clon $3\left(\mathrm{C}_{3}-\mathrm{FCA}\right)$ \\
Córdoba & Clon $8\left(\mathrm{C}_{8}-\mathrm{FCA}\right)$ \\
& Negrito $(\mathrm{NB}-\mathrm{TS})$ \\
& Mendocino $(\mathrm{Me}-\mathrm{TS})$ \\
& Verde Limón $(\mathrm{VL}-\mathrm{TS})$ \\
\hline San Juan & Negrito $(\mathrm{Ne}-\mathrm{SJ})$ \\
\hline
\end{tabular}

Mza: Mendoza; FCA: Facultad de Ciencias Agropecuarias; TS: Traslasierra Valley; SJ: San Juan.

Regarding to the agronomic evaluation of oregano cultivated in Argentina, in addition, the agronomic performance assessment of the growing materials [14-18], the study of different types of irrigation $[19,20]$, different methods of drying and storage [21-25], and the characterization of essential oils (yield and composition) [12, 26-28] was carried out. Besides, Farías et al. [10] generated a list of 41 descriptors of oregano, with the aim of facilitating the identification, and characterization of different clones.

From the characterization of genotypes of oregano grown in the country, in terms of agronomic performance, morphology, botanical identification and study of essential oils, it is possible to plan the competitive development of this aromatic herb of great commercial value.

According to the above, the aims of this study were (1) to evaluate and characterize twelve genotypes of oregano grown in major production areas of the country through agronomically important variables, (2) to establish traits with the highest discriminant value to distinguish the genotypes of oregano, and (3) to carry out the taxonomic identification of these clones.

\section{Materials and Methods}

2.1. Plant Material. During spring and summer season of 2006/2007, plants belonging to twelve oregano clones coming from different collection sites were sanitized by meristem culture and micropropagated in vitro in order to use them as mother plants (Table 1). During autumn season of 2008, those mother plants were placed in pots containing vermiculite, irrigated with a nutrient and fungicidal solution, and maintained under the greenhouse environmental conditions. A month after transplanting, these mother plants were multiplied by binodal cuttings to get the number of plants needed to carry out the field essays. Plants grown from cuttings binodal were maintained under controlled environmental conditions until transplanting to the field in spring of 2008.
TABLE 2: Weather characteristics from the three culture locations where the comparative essays were implanted.

\begin{tabular}{lcccc}
\hline Locations & Altitude $(\mathrm{mosl})$ & $\mathrm{JaMT}\left({ }^{\circ} \mathrm{C}\right)$ & $\mathrm{JuMT}\left({ }^{\circ} \mathrm{C}\right)$ & $\mathrm{MAP}(\mathrm{mm})$ \\
\hline LC-Mza & 954 & 21.8 & 6.2 & 212.5 \\
PG-Cba & 810 & 21.3 & 9.9 & 723.3 \\
CE-Cba & 370 & 22.8 & 9.7 & 606.5 \\
\hline
\end{tabular}

mosl: meters over sea level; JaMT: January mean temperature; JuMT: July mean temperature; MAP: mean annual precipitation. LC-Mza: La Consulta (Mendoza); PG-Cba: Potrero de Garay (Córdoba); CE-Cba: Campo Escuela FCA-UNC (Córdoba).

2.2. Field Essays. In spring season of 2008, three field essays were conducted in order to evaluate the agronomic performance of twelve genotypes of oregano. They were implanted in three different locations: the Agricultural Experiment Station La Consulta: INTA $\left(33^{\circ} 29^{\prime} \mathrm{S}, 69^{\circ} 04^{\prime}\right.$ O, San Carlos, Mendoza), a private farm in Potrero de Garay $\left(31^{\circ} 47^{\prime}\right.$ S, $64^{\circ} 33^{\prime}$ O, Santa María, Córdoba) and the Experimental Farm of the Faculty of Agricultural Sciences at the Universidad Nacional de Córdoba, $\left(31^{\circ} 29^{\prime} \mathrm{S}, 64^{\circ} 00^{\prime}\right.$ $\mathrm{O}$, Capilla de los Remedios road, $15.5 \mathrm{Km}$, Córdoba). The weather characteristics from the three culture locations are described in Table 2.

In every location, the oregano plants were transplanted following a completely randomized design, where each of the 12 clones was represented by 10 plants. The plants were distributed in lines spaced at $0.70 \mathrm{~m}$ apart with a distance of $0.25 \mathrm{~m}$ between plants on the line. The essays were watered twice a week, especially during the summer, and the cultural labors required for the proper development of the culture (as weeding) were also carried out.

The different genotypes were evaluated based on their morphological, phonological, and yield characteristics. Along the growing season, the longest branch length (LBL*) $(\mathrm{cm})$ was measured. Three months after planting, the first harvest was carried out (all plants were harvested individually and correctly identified) and internode length (IL) $(\mathrm{cm})$, fresh weight $\left(\mathrm{FW}^{*}\right)\left(\mathrm{g}\right.$ plant $\left.^{-1}\right)$, dry weight $\left(\mathrm{DW}^{*}\right)$ $\left(\mathrm{g} \mathrm{plant}^{-1}\right)$, leave dry weight $\left(\mathrm{LDW}^{*}\right)\left(\mathrm{g} \mathrm{plant}^{-1}\right)$, and stem dry weight $\left(\mathrm{SDW}^{*}\right)\left(\mathrm{g}\right.$ plant $\left.^{-1}\right)$ were also measured. To determine the leaf area (LA) $\left(\mathrm{cm}^{2}\right)$, fully expanded leaves located in the middle third of each branch were taken and scanned; for the image processing, software ImageJ (ver. X.XX, NIH, USA) was used. In order to estimate the essential oil content (EO) (\%), from each one of the clones under study, three samples of dry leaves $(5 \mathrm{~g}$ each) were taken. The oil extraction was carried out for 45 minutes, by hydrodistillation in a modified Clevenger equipment; subsequently, oil content was expressed in $\mathrm{mL}$ per $100 \mathrm{~g}$ of dry material. Besides, the ratio leave dry weight/stem dry weight $\left(\mathrm{L} / \mathrm{S}^{*}\right)$, water content (WC) $(\%)$ and fiber content (FC) (\%) were estimated. One year after planting, a second harvest was carried out and the longest branch length $\left(\mathrm{LBL}^{* *}\right)(\mathrm{cm})$, number of branches $\left(\mathrm{n}^{\circ} \mathrm{plant}^{-1}\right)$ fresh weight $\left(\mathrm{FW}^{* *}\right)\left(\mathrm{g} \mathrm{plant}^{-1}\right)$, and dry weight $\left(\mathrm{DW}^{* *}\right)\left(\mathrm{g} \mathrm{plant}^{-1}\right)$ were registered. 
TABLE 3: Quantitative trait mean values for the twelve clones of oregano evaluated in La Consulta (San Carlos, Mendoza).

\begin{tabular}{|c|c|c|c|c|c|c|c|c|c|c|c|c|c|c|c|}
\hline Clon & $\begin{array}{l}\mathrm{LBL}_{1} \\
(\mathrm{~cm})\end{array}$ & $\begin{array}{c}\mathrm{IL} \\
(\mathrm{cm})\end{array}$ & $\begin{array}{c}\mathrm{LA} \\
\left(\mathrm{cm}^{2}\right)\end{array}$ & $\begin{array}{c}\mathrm{FW}^{*} \\
\left(\mathrm{~g} \mathrm{pl}^{-1}\right)\end{array}$ & $\begin{array}{c}\mathrm{DW}^{*} \\
\left(\mathrm{~g} \mathrm{pl}^{-1}\right)\end{array}$ & $\begin{array}{l}\mathrm{LDW}^{*} \\
\left(\mathrm{~g} \mathrm{pl}^{-1}\right)\end{array}$ & $\begin{array}{l}\mathrm{SDW}^{*} \\
\left(\mathrm{~g} \mathrm{pl}^{-1}\right)\end{array}$ & $\mathrm{L} / \mathrm{S}^{*}$ & $\begin{array}{l}\mathrm{EO} \\
(\%)\end{array}$ & $\begin{array}{c}\text { WC* }^{*} \\
(\%)\end{array}$ & $\begin{array}{l}\mathrm{FC}^{*} \\
(\%)\end{array}$ & $\begin{array}{l}\mathrm{LBL}_{2} \\
(\mathrm{~cm})\end{array}$ & $\begin{array}{c}\text { Branch } \\
\left(N^{\circ}\right)\end{array}$ & $\begin{array}{c}\mathrm{FW}^{* *} \\
\left(\mathrm{~g} \mathrm{pl}^{-1}\right)\end{array}$ & $\begin{array}{c}\mathrm{DW}^{* *} \\
\left(\mathrm{~g} \mathrm{pl}^{-1}\right)\end{array}$ \\
\hline Me-TS & $19.02 \mathrm{a}$ & $2.27 \mathrm{~b}$ & $0.36 a$ & $60.61 \mathrm{a}$ & $18.73 a$ & $14.34 \mathrm{a}$ & $4.39 \mathrm{a}$ & $3.31 \mathrm{a}$ & $2.00 \mathrm{~d}$ & $69.15 b$ & $30.90 \mathrm{a}$ & $47.34 \mathrm{a}$ & $94 a$ & $272 \mathrm{a}$ & $107.5 \mathrm{a}$ \\
\hline VL-TS & $23.42 \mathrm{a}$ & $2.53 c$ & $0.53 c$ & $52.80 \mathrm{a}$ & $16.79 \mathrm{a}$ & $11.32 \mathrm{a}$ & $5.48 \mathrm{a}$ & $2.02 \mathrm{a}$ & $0.72 b$ & $68.41 \mathrm{~b}$ & $31.80 \mathrm{a}$ & $54.86 \mathrm{c}$ & $112 \mathrm{a}$ & $240 \mathrm{a}$ & $106.0 \mathrm{a}$ \\
\hline NB-TS & $29.59 b$ & $2.16 \mathrm{~b}$ & $0.57 \mathrm{c}$ & $73.72 \mathrm{a}$ & $23.08 \mathrm{a}$ & $17.75 b$ & $5.33 \mathrm{a}$ & $4.07 \mathrm{~b}$ & $0.83 b$ & $68.17 \mathrm{~b}$ & $31.30 \mathrm{a}$ & $56.01 \mathrm{c}$ & $97 \mathrm{a}$ & $282 \mathrm{a}$ & $105.1 \mathrm{a}$ \\
\hline $\mathrm{Ne}-\mathrm{SJ}$ & $30.93 b$ & $1.82 \mathrm{a}$ & $0.84 \mathrm{~d}$ & $87.31 \mathrm{~b}$ & $25.51 \mathrm{a}$ & $20.65 b$ & $4.86 a$ & & $0.35 a$ & $70.38 \mathrm{~b}$ & $29.21 \mathrm{a}$ & $46.04 a$ & $101 \mathrm{a}$ & & $108.5 \mathrm{a}$ \\
\hline Me-Mza & $28.56 \mathrm{~b}$ & $2.59 c$ & $0.49 \mathrm{~b}$ & & $19.07 \mathrm{a}$ & & & & $2.36 \mathrm{e}$ & & & $52.56 \mathrm{~b}$ & & & \\
\hline $\mathrm{Cm}-\mathrm{Mza}$ & $30.02 \mathrm{~b}$ & $2.17 \mathrm{~b}$ & $0.53 c$ & $80.41 \mathrm{a}$ & $22.94 \mathrm{a}$ & & $4.30 \mathrm{a}$ & & $0.91 b$ & & $28.53 a$ & $56.77 \mathrm{c}$ & $118 \mathrm{a}$ & & $118.5 \mathrm{a}$ \\
\hline Cd-Mza & $32.86 \mathrm{~b}$ & $1.66 \mathrm{a}$ & $0.40 \mathrm{a}$ & $62.70 \mathrm{a}$ & $21.08 \mathrm{a}$ & & $6.56 \mathrm{a}$ & & $1.42 \mathrm{c}$ & $65.96 \mathrm{a}$ & $33.62 b$ & $46.33 a$ & $109 a$ & & $110.0 \mathrm{a}$ \\
\hline Cr-Mza & $34.49 \mathrm{~b}$ & $2.13 \mathrm{~b}$ & $0.49 \mathrm{~b}$ & $50.87 \mathrm{a}$ & $17.94 \mathrm{a}$ & & $6.13 \mathrm{a}$ & & $1.35 \mathrm{c}$ & $64.42 \mathrm{a}$ & $35.27 \mathrm{~b}$ & $57.21 \mathrm{c}$ & & & $128.9 a$ \\
\hline $\mathrm{C}_{1}$-FCA & $38.86 \mathrm{~b}$ & $1.94 \mathrm{~b}$ & $0.45 b$ & $66.97 a$ & $22.39 a$ & & $6.73 a$ & & $1.42 \mathrm{c}$ & $66.53 a$ & $33.43 b$ & $57.28 \mathrm{c}$ & & & \\
\hline $\mathrm{C}_{2}$-FCA & $37.72 \mathrm{~b}$ & $2.04 \mathrm{~b}$ & $0.40 \mathrm{a}$ & $74.47 \mathrm{a}$ & $25.56 \mathrm{a}$ & $17.73 b$ & $7.83 b$ & $2.30 \mathrm{a}$ & $1.55 \mathrm{c}$ & $65.76 \mathrm{a}$ & $34.32 \mathrm{~b}$ & $57.74 \mathrm{c}$ & $119 a$ & $334 a$ & $142.5 \mathrm{a}$ \\
\hline $\mathrm{C}_{3}-\mathrm{FCA}$ & $23.04 \mathrm{a}$ & $1.68 \mathrm{a}$ & $0.47 \mathrm{~b}$ & $94.12 \mathrm{~b}$ & $28.58 \mathrm{a}$ & $20.33 b$ & $8.25 b$ & $2.78 \mathrm{a}$ & $0.50 \mathrm{a}$ & $69.72 b$ & $30.37 a$ & $51.68 \mathrm{~b}$ & $102 \mathrm{a}$ & $544 \mathrm{~b}$ & $191.1 \mathrm{~b}$ \\
\hline $\mathrm{C}_{8}-\mathrm{FCA}$ & $35.99 b$ & $1.75 \mathrm{a}$ & $0.49 \mathrm{~b}$ & $98.89 b$ & $31.50 \mathrm{~b}$ & $23.66 \mathrm{~b}$ & $7.84 b$ & $3.29 \mathrm{a}$ & $0.66 \mathrm{~b}$ & $68.24 \mathrm{~b}$ & $31.85 \mathrm{a}$ & $51.82 \mathrm{~b}$ & $103 a$ & $544 \mathrm{~b}$ & $192.0 \mathrm{~b}$ \\
\hline
\end{tabular}

$C_{1}$-FCA: clone 1, $C_{2}$-FCA: clone 2, $C_{3}$-FCA: clone 3, $C_{8}$-FCA: clone 8, Me-Mza: clone "Mendocino," Cm-Mza: clone "Compacto," Cd-Mza: clone "Cordobés," Cr-Mza: clone "Criollo," Me-TS: clone "Mendocino," NB-TS: clone "Negrito B,” VL-TS: clone "Verde Limón,” Ne-SJ: clone "Negrito," LBL: longest branch length; IL: internode length, LA: leaf area, FW: fresh weight, DW: dry weight, LDW: leave dry weight, SDW: stem dry weight, L/S: ratio LDW/SDW, EO: essential oil content, WC: water content, FC: fiber content, ${ }^{*}$ measured at 1 st harvest, ${ }^{* *}$ measured at 2 nd harvest, ${ }^{1}$ three month after sowing, ${ }^{2}$ one year after sowing. Different letters indicate significant differences $(P \leq 0.05)$.

2.3. Taxonomic Identification. In order to determine the taxonomic name of the twelve evaluated clones, one flowering branch belonging to every clone was collected, herborized and conserved in the Museo Botánico del Instituto Multidisciplinario de Biología Vegetal Herbarium (IMBIV). The botanical characterization, mainly based in floral characters, was carried out using the identification keys of Ietswaart [29], Xifreda [2], and Rouquaud and Videla [3].

2.4. Statistical Analysis. All results obtained for each of the measured variables were analyzed using the software INFOSTAT [30].

The differences among clones and growing locations for each one of the evaluated variables were estimated using an ANOVA according to the following model:

$$
Y_{i j k}=\mu+C_{i}+L_{j}+L_{j}>R_{k}+C * L_{i j}+\varepsilon_{i j k},
$$

where $Y_{i j k}$ represents the average value of each variable of the $i$ th clone $\left(C_{i}\right)$ evaluated at the $j$ th location $\left(L_{j}\right), R_{k}$ is the number of repetitions of each clone in every location, $C * L_{i j}$ is the interaction between the $i$ th clone, and $j$ th location and $E_{i j k}$ with $\sim N\left(0, S^{2}\right)$ is the random error term associated with observation $Y_{i j k}$. Differences between mean values of each clone and location were determined using the posteriori test for comparison of means DGC [31].

By using the principal component analysis (PCA) that was assessed the potentiality of quantitative traits measured was assessed, in order to discriminate the different clones in each growing environment. Finally, a Generalized Procrustes Analysis (GPA) was conducted in order to determine the level of consensus between the configurations obtained for all evaluated characters in each growing location, in other words to determine whether the variables have the same discriminant value in all growing environment.

\section{Results and Discussion}

Significant differences among the twelve evaluated clones were observed in most of quantitative traits measured in all cultivation locations (Tables 3, 4, and 5). The agronomic performance of 12 clones evaluated in each cultivation sites is described below.

3.1. La Consulta INTA Essay. Clones Me-TS, VL-TS, and $\mathrm{C}_{3}$ FCA showed the lower mean value for longest branch length, when this trait was measured three months after sowing. One year after sowing, the clones with the lower longest branch length mean value were Me-TS, Ne-SJ, and Cd-Mza.

Regarding the fresh weight yield of the first harvest, clones $\mathrm{C}_{8}$-FCA, $\mathrm{C}_{3}$-FCA, and $\mathrm{Ne}-\mathrm{SJ}$ stood out for their higher production of fresh biomass, followed by clones $\mathrm{Cm}-\mathrm{Mza}$ and NB-TS. In relation to dry weight, again $\mathrm{C}_{8}$-FCA clone differed significantly from the other clones because of its greater dry biomass yields, followed by clones $\mathrm{C}_{3}-\mathrm{FCA}, \mathrm{C}_{2}$ FCA, Ne-SJ, Cm-Mza and NB-TS. The production of fresh and dry biomass can be related to the length of the internodes and leaf area; clones $\mathrm{C}_{3}$-FCA, $\mathrm{C}_{2}$-FCA, Ne-SJ, Cm-Mza, and NB-TS also showed shorter internodes and greater area leaf (Table 3). In the second harvest, clones $\mathrm{C}_{3}$-FCA and $\mathrm{C}_{8}$-FCA significantly surpassed the rest of the material for both fresh and dry weight. Regardless of the clone, the fresh and dry weight yields observed in both harvests are generally similar to those reported by Droushiotis and Della [32] and Weglarz and Geszprych [33].

With regard to the percentage of water that is lost during the drying process, significant differences were observed among the clones both in the first as in the second harvest. In the first harvest, the clones with the lowest content of water were Cr-Mza, $\mathrm{C}_{2}$-FCA, Cd-Mza, and $\mathrm{C}_{1}$-FCA, which in turn showed the highest percentage of fibers $(66.47 \%$, and $34.16 \%$ 
TABLE 4: Quantitative trait mean values for the twelve clones of oregano evaluated in Potreto de Garay (Santa María, Córdoba).

\begin{tabular}{|c|c|c|c|c|c|c|c|c|c|c|c|c|c|c|c|}
\hline Clon & $\begin{array}{l}\mathrm{LBL}_{1} \\
(\mathrm{~cm})\end{array}$ & $\begin{array}{c}\mathrm{IL} \\
(\mathrm{cm})\end{array}$ & $\begin{array}{c}\mathrm{LA} \\
\left(\mathrm{cm}^{2}\right)\end{array}$ & $\begin{array}{c}\mathrm{FW}^{*} \\
\left(\mathrm{~g} \mathrm{pl}^{-1}\right)\end{array}$ & $\begin{array}{c}\mathrm{DW}^{*} \\
\left(\mathrm{~g} \mathrm{pl}^{-1}\right)\end{array}$ & $\begin{array}{l}\mathrm{LDW}^{*} \\
\left(\mathrm{~g} \mathrm{pl}^{-1}\right)\end{array}$ & $\begin{array}{l}\mathrm{SDW}^{*} \\
\left(\mathrm{~g} \mathrm{pl}^{-1}\right)\end{array}$ & $\mathrm{L} / \mathrm{S}^{*}$ & $\begin{array}{l}\mathrm{EO} \\
(\%)\end{array}$ & $\begin{array}{c}\text { WC* }^{*} \\
(\%)\end{array}$ & $\begin{array}{l}\mathrm{FC}^{*} \\
(\%)\end{array}$ & $\begin{array}{l}\mathrm{LBL}_{2} \\
(\mathrm{~cm})\end{array}$ & $\begin{array}{c}\text { Branch } \\
\left(N^{\circ}\right)\end{array}$ & $\begin{array}{c}\mathrm{FW}^{* *} \\
\left(\mathrm{~g} \mathrm{pl}^{-1}\right)\end{array}$ & $\begin{array}{c}\mathrm{DW}^{* *} \\
\left(\mathrm{~g} \mathrm{pl}^{-1}\right)\end{array}$ \\
\hline Me-TS & $28.04 \mathrm{a}$ & $0.96 a$ & $0.68 b$ & $8.90 \mathrm{a}$ & $5.53 \mathrm{a}$ & $2.51 \mathrm{a}$ & $3.02 \mathrm{a}$ & $0.73 a$ & $3.11 \mathrm{c}$ & $39.39 a$ & $62.13 \mathrm{~b}$ & $21.43 a$ & $30 \mathrm{~b}$ & $31.97 \mathrm{a}$ & $13.76 \mathrm{a}$ \\
\hline VL-TS & $32.25 \mathrm{a}$ & $1.08 \mathrm{~b}$ & $0.36 a$ & $36.50 \mathrm{~b}$ & $16.22 b$ & $10.64 \mathrm{~b}$ & $5.58 \mathrm{a}$ & $1.68 \mathrm{~b}$ & $0.71 \mathrm{a}$ & $49.58 \mathrm{~b}$ & $44.44 \mathrm{a}$ & $24.16 \mathrm{a}$ & $30 \mathrm{~b}$ & $37.79 \mathrm{a}$ & $15.80 \mathrm{a}$ \\
\hline NB-TS & $28.75 a$ & $1.17 \mathrm{~b}$ & $1.06 \mathrm{~d}$ & $54.85 \mathrm{c}$ & $22.47 \mathrm{c}$ & $15.99 \mathrm{c}$ & $6.48 \mathrm{a}$ & $2.58 \mathrm{c}$ & $0.43 \mathrm{a}$ & $57.26 \mathrm{c}$ & $40.97 \mathrm{a}$ & $31.12 \mathrm{~b}$ & $68 \mathrm{~d}$ & $145.73 c$ & $56.30 \mathrm{c}$ \\
\hline $\mathrm{Ne}-\mathrm{SJ}$ & $41.54 \mathrm{~b}$ & $1.14 \mathrm{~b}$ & $0.65 b$ & $61.70 \mathrm{c}$ & $25.11 \mathrm{c}$ & $18.62 \mathrm{c}$ & $6.49 a$ & $3.30 \mathrm{~d}$ & $0.36 \mathrm{a}$ & $58.89 c$ & $40.70 \mathrm{a}$ & $36.41 \mathrm{~b}$ & $83 d$ & & $64.94 c$ \\
\hline Me-Mza & $33.18 \mathrm{a}$ & $0.91 \mathrm{a}$ & $0.53 b$ & & $5.05 \mathrm{a}$ & & & & $4.63 d$ & & $59.06 \mathrm{~b}$ & & & & \\
\hline $\mathrm{Cm}-\mathrm{Mza}$ & $26.90 \mathrm{a}$ & $1.14 \mathrm{~b}$ & $0.92 \mathrm{c}$ & $60.30 c$ & $25.11 \mathrm{c}$ & & & & $0.41 \mathrm{a}$ & & & $32.50 \mathrm{~b}$ & $76 \mathrm{~d}$ & & $57.19 c$ \\
\hline Cd-Mza & $29.17 \mathrm{a}$ & $1.09 \mathrm{~b}$ & $0.55 b$ & $21.35 \mathrm{a}$ & $9.91 \mathrm{~b}$ & & & & $1.46 \mathrm{~b}$ & $53.94 \mathrm{c}$ & & & $38 \mathrm{~b}$ & & $28.28 \mathrm{~b}$ \\
\hline Cr-Mza & $33.60 \mathrm{a}$ & $1.35 \mathrm{c}$ & $0.61 \mathrm{~b}$ & $31.35 b$ & $13.21 \mathrm{~b}$ & & & & $1.19 \mathrm{~b}$ & $55.72 c$ & & $35.53 b$ & & & $37.23 b$ \\
\hline $\mathrm{C}_{1}-\mathrm{FCA}$ & $35.42 \mathrm{a}$ & $1.17 \mathrm{~b}$ & $0.56 \mathrm{~b}$ & $35.85 \mathrm{~b}$ & $16.80 \mathrm{~b}$ & $10.42 \mathrm{~b}$ & $6.38 \mathrm{a}$ & & $1.49 \mathrm{~b}$ & $47.44 \mathrm{~b}$ & $46.86 \mathrm{a}$ & $35.14 \mathrm{~b}$ & $57 c$ & & $46.49 \mathrm{~b}$ \\
\hline $\mathrm{C}_{2}$-FCA & $33.27 \mathrm{a}$ & $1.11 \mathrm{~b}$ & $0.61 b$ & $35.75 b$ & $16.81 \mathrm{~b}$ & $10.70 \mathrm{~b}$ & $6.11 \mathrm{a}$ & $1.75 \mathrm{~b}$ & $1.56 \mathrm{~b}$ & $53.03 c$ & $47.02 \mathrm{a}$ & $34.42 \mathrm{~b}$ & $54 c$ & $95.23 b$ & $40.07 \mathrm{~b}$ \\
\hline $\mathrm{C}_{3}-\mathrm{FCA}$ & $36.91 \mathrm{a}$ & $1.22 \mathrm{~b}$ & $0.44 a$ & $42.79 \mathrm{~b}$ & $18.28 \mathrm{~b}$ & $12.21 \mathrm{~b}$ & $7.58 \mathrm{a}$ & $1.66 \mathrm{~b}$ & $1.00 \mathrm{~b}$ & $55.33 c$ & $42.72 \mathrm{a}$ & $47.10 \mathrm{~d}$ & $53 \mathrm{c}$ & $143.99 \mathrm{c}$ & $57.38 \mathrm{c}$ \\
\hline $\mathrm{C}_{8}-\mathrm{FCA}$ & $38.16 \mathrm{a}$ & $1.22 \mathrm{~b}$ & $0.41 \mathrm{a}$ & $68.50 c$ & $29.54 c$ & $16.33 c$ & $13.20 \mathrm{~b}$ & $1.72 b$ & $1.01 \mathrm{~b}$ & $56.39 \mathrm{c}$ & $43.12 \mathrm{a}$ & $41.88 \mathrm{c}$ & $61 c$ & $135.78 c$ & $55.02 \mathrm{c}$ \\
\hline
\end{tabular}

$\mathrm{C}_{1}$-FCA: clone 1, $\mathrm{C}_{2}$-FCA: clone 2, $\mathrm{C}_{3}$-FCA: clone 3, $\mathrm{C}_{8}$-FCA: clone 8, Me-Mza: clone "Mendocino", Cm-Mza: clone "Compacto," Cd-Mza: clone "Cordobés," Cr-Mza: clone "Criollo," Me-TS: clone "Mendocino," NB-TS: clone "Negrito B,” VL-TS: clone "Verde Limón,” Ne-SJ: clone "Negrito," LBL: longest branch length, IL: internode length, LA: leaf area, FW: fresh weight, DW: dry weight, LDW: leave dry weight, SDW: stem dry weight, L/S: ratio LDW/SDW, EO: essential oil content, WC: water content, FC: fiber content, ${ }^{*}$ measured at 1 st harvest, ${ }^{* *}$ measured at 2 nd harvest, ${ }^{1}$ three month after sowing, ${ }^{2}$ one year after sowing. Different letters indicate significant differences $(P \leq 0.05)$.

TABLE 5: Quantitative trait mean values for the twelve clones of oregano evaluated in Capilla de los Remedios (Río Segundo, Córdoba).

\begin{tabular}{|c|c|c|c|c|c|c|c|c|c|c|c|c|c|c|c|}
\hline Clon & $\begin{array}{l}\mathrm{LBL}_{1} \\
(\mathrm{~cm})\end{array}$ & $\begin{array}{c}\mathrm{IL} \\
(\mathrm{cm})\end{array}$ & $\begin{array}{c}\mathrm{LA} \\
\left(\mathrm{cm}^{2}\right)\end{array}$ & $\begin{array}{c}\mathrm{FW}^{*} \\
\left(\mathrm{~g} \mathrm{pl}^{-1}\right)\end{array}$ & $\begin{array}{c}\mathrm{DW}^{*} \\
\left(\mathrm{~g} \mathrm{pl}^{-1}\right)\end{array}$ & $\begin{array}{l}\mathrm{LDW}^{*} \\
\left(\mathrm{~g} \mathrm{pl}^{-1}\right)\end{array}$ & $\begin{array}{l}\mathrm{SDW}^{*} \\
\left(\mathrm{~g} \mathrm{pl}^{-1}\right)\end{array}$ & $\mathrm{L} / \mathrm{S}^{*}$ & $\begin{array}{l}\text { EO } \\
(\%)\end{array}$ & $\begin{array}{c}\text { WC* } \\
(\%)\end{array}$ & $\begin{array}{l}\mathrm{FC}^{*} \\
(\%)\end{array}$ & $\begin{array}{l}\mathrm{LBL}_{2} \\
(\mathrm{~cm})\end{array}$ & $\begin{array}{c}\text { Branch } \\
\left(N^{\circ}\right)\end{array}$ & $\begin{array}{c}\mathrm{FW}^{* *} \\
\left(\mathrm{~g} \mathrm{pl}^{-1}\right)\end{array}$ & $\begin{array}{l}\mathrm{DW}^{* *} \\
\left(\mathrm{~g} \mathrm{pl}^{-1}\right)\end{array}$ \\
\hline & $26.01 \mathrm{~b}$ & $124 \mathrm{~b}$ & $0.53 a$ & $113.55 \mathrm{a}$ & 3512 & 25040 & $9.18 \mathrm{a}$ & & $1.91 \mathrm{~b}$ & $69.58 \mathrm{a}$ & $30.93 b$ & $22.91 \mathrm{~b}$ & & & $29.06 a$ \\
\hline & $14.03 \mathrm{a}$ & $0.75 \mathrm{a}$ & $0.48 \mathrm{a}$ & $113.48 \mathrm{a}$ & $31.85 \mathrm{a}$ & $20.07 \mathrm{a}$ & $11.78 \mathrm{a}$ & $2.09 \mathrm{a}$ & $0.52 \mathrm{a}$ & $72.04 \mathrm{a}$ & $28.07 \mathrm{~b}$ & $17.30 \mathrm{a}$ & $97 \mathrm{a}$ & $28.36 \mathrm{a}$ & $12.55 \mathrm{a}$ \\
\hline & $17.04 \mathrm{a}$ & $0.90 \mathrm{a}$ & $0.71 b$ & $227.26 b$ & $63.99 b$ & $45.92 b$ & $18.07 \mathrm{a}$ & $3.16 \mathrm{~b}$ & $0.80 \mathrm{a}$ & $72.03 a$ & $28.16 \mathrm{~b}$ & $25.78 \mathrm{~b}$ & $188 \mathrm{~b}$ & $134.77 b$ & $53.88 \mathrm{~b}$ \\
\hline $\mathrm{Ne}-\mathrm{SJ}$ & $21.22 \mathrm{a}$ & $0.86 a$ & $0.96 c$ & $275.49 b$ & $84.81 \mathrm{~b}$ & $53.99 b$ & $30.82 b$ & $2.27 \mathrm{a}$ & $0.41 \mathrm{a}$ & $69.45 a$ & $30.79 b$ & $13.37 \mathrm{a}$ & $74 \mathrm{a}$ & $50.01 \mathrm{a}$ & $16.75 a$ \\
\hline Me-Mza & $31.86 \mathrm{~b}$ & $1.29 \mathrm{~b}$ & $0.57 \mathrm{a}$ & $143.58 \mathrm{a}$ & $43.60 \mathrm{a}$ & $31.10 \mathrm{a}$ & $12.50 \mathrm{a}$ & $2.70 \mathrm{a}$ & $2.38 \mathrm{c}$ & $70.16 a$ & $30.37 b$ & $31.96 \mathrm{~b}$ & $76 a$ & $93.35 b$ & $42.15 b$ \\
\hline Cm-Mza & $16.26 \mathrm{a}$ & $0.87 \mathrm{a}$ & $0.74 b$ & $211.80 \mathrm{~b}$ & $62.86 \mathrm{~b}$ & & & & $0.76 a$ & & $29.68 b$ & $28.51 b$ & $147 \mathrm{a}$ & & \\
\hline & $26.59 \mathrm{~b}$ & $1.38 \mathrm{~b}$ & $0.62 \mathrm{a}$ & & & & & & $1.11 \mathrm{a}$ & & & & & & \\
\hline Cr-Mza & $26.49 \mathrm{~b}$ & $1.34 \mathrm{~b}$ & $0.60 \mathrm{a}$ & & & & & $1.54 \mathrm{a}$ & $0.88 \mathrm{a}$ & & & $40.55 c$ & & & \\
\hline $\mathrm{C}_{1}$-FCA & $31.67 \mathrm{~b}$ & $1.22 \mathrm{~b}$ & $0.52 \mathrm{a}$ & & $37.81 \mathrm{a}$ & & & $1.65 \mathrm{a}$ & $0.73 a$ & & & $29.46 b$ & & & $47.33 \mathrm{~b}$ \\
\hline $\mathrm{C}_{2}$-FCA & $25.96 \mathrm{~b}$ & $1.24 \mathrm{~b}$ & $0.52 \mathrm{a}$ & & & & & & $0.82 \mathrm{a}$ & & & & & & $57.39 \mathrm{~b}$ \\
\hline & $19.71 \mathrm{a}$ & $0.87 \mathrm{a}$ & $0.69 b$ & & & & & & $0.33 \mathrm{a}$ & & & & & & \\
\hline $\mathrm{C}_{8}-\mathrm{FCA}$ & $16.32 \mathrm{a}$ & $0.82 \mathrm{a}$ & $0.61 \mathrm{a}$ & $188.87 \mathrm{~b}$ & $45.98 \mathrm{a}$ & $32.18 \mathrm{a}$ & $13.80 \mathrm{a}$ & $2.79 a$ & $0.52 \mathrm{a}$ & $75.12 b$ & $24.34 \mathrm{a}$ & $24.12 b$ & $110 \mathrm{a}$ & $80.98 \mathrm{~b}$ & $31.43 \mathrm{a}$ \\
\hline
\end{tabular}

$\mathrm{C}_{1}$-FCA: clone $1 \mathrm{C}_{2}$-FCA: clone 2, $\mathrm{C}_{3}$-FCA: clone 3, $\mathrm{C}_{8}$-FCA: clone 8, Me-Mza: clone "Mendocino," Cm-Mza: clone "Compacto," Cd-Mza: clone "Cordobés," Cr-Mza: clone "Criollo," Me-TS: clone "Mendocino," NB-TS: clone "Negrito B,” VL-TS: clone "Verde Limón,” Ne-SJ: clone "Negrito," LBL: longest branch length, IL: internode length, LA: leaf area, FW: fresh weight, DW: dry weight, LDW: leave dry weight, SDW: stem dry weight, L/S: ratio LDW/SDW, EO: essential oil content, WC: water content, FC: fiber content, ${ }^{*}$ measured at 1 st harvest, ${ }^{* *}$ measured at 2 nd harvest, ${ }^{1}$ three month after sowing, ${ }^{2}$ one year after sowing. Different letters indicate significant differences $(P \leq 0.05)$.

resp.). In the second harvest, the clones with lowest water content and higher fiber content were Cd-Mza, VL-TS, and $\mathrm{C}_{2}-\mathrm{FCA}$, with an average percentage of $54.68 \%$ of water and $45.32 \%$ fiber. The percentage of water found in the second harvest was similar to that reported by Leto and Salamone [34], who studied 62 biotypes of oregano coming from 17 different locations. Higher fiber content (or less water loss) is equivalent to a higher dry matter yield. That is, on average, those clones with higher fiber content showed a dry matter yield $7.62 \%$ higher than the rest of the clones in the first crop and $15.85 \%$ in the second harvest. This is important when estimating production volumes of dry matter.
Significant differences were also observed among the clones in terms of dry weight of leaves and stems and leaf/stem ratio (Table 3), being this latter variable very important when estimating the returns as are leaves the part of the plant that is consumed [35]. Clones that showed the highest values for leaf/stem ratio were Ne-SJ, Cm-Mza, and NB-TS, these clones had short internodes, a greater number of nodes (and therefore more foliage), and greater leaf area.

Based on the essential oil yield, it was possible to distinguish four groups of oregano. The first group showed an average essential oil content of $2.18 \%$ which includes the clones Me-Mza and Me-TS. The second group, including 


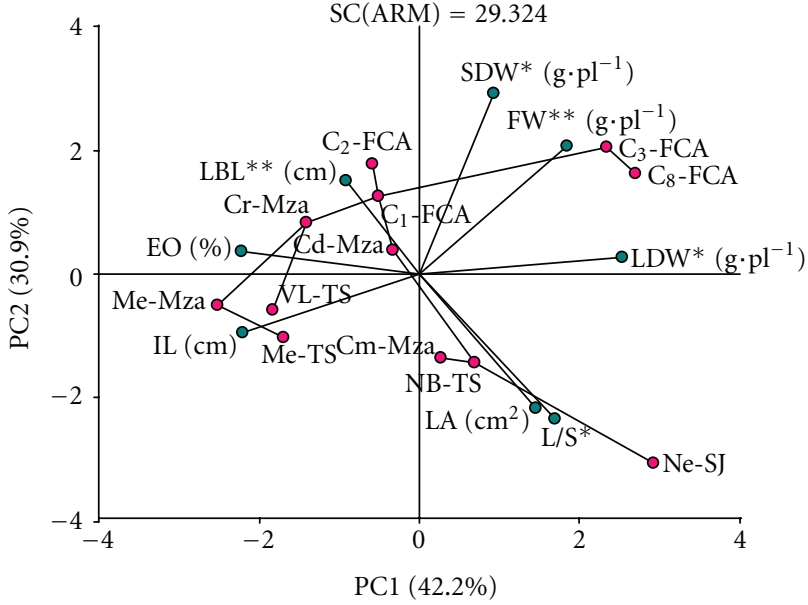

Figure 1: Biplot plane formed by the two first principal components ( $\mathrm{CP} 1$ and $\mathrm{CP} 2$ ), where the dots represent the 12 clones of oregano evaluated and the vectors, quantitative characteristics measured in La Consulta (Mendoza). $\mathrm{C}_{1}$-FCA: clone 1, $\mathrm{C}_{2}$-FCA: clone 2, $\mathrm{C}_{3}$-FCA: clone 3, $\mathrm{C}_{8}$-FCA: clone 8, Me-Mza: clone "Mendocino," Cm-Mza: clone "Compacto," Cd-Mza: clone "Cordobés," Cr-Mza: clone "Criollo," Me-TS: clone "Mendocino," NB-TS: clone "Negrito B," VL-TS: clone "Verde Limón," Ne-SJ: clone "Negrito," LBL: longest branch length, IL: internode length; LA: leaf area, FW: fresh weight, LDW: leave dry weight, SDW: stem dry weight, L/S: ratio LDW/SDW, EO: essential oil content, * measured at 1st harvest (three month after sowing); ${ }^{* *}$ measured at 2 nd harvest (one year after sowing).

the clones $\mathrm{C}_{2}$-FCA, $\mathrm{C}_{1}$-FCA, Cd-Mza and Cr-Mza, showed an average essential oil content of $1.44 \%$, while the third group, involving the clones Cm-Mza, NB-TS, VL-TS $y \mathrm{C}_{8}$ FCA, showed an average oil percentage of $0.78 \%$. Finally, the group with the lowest essential oil content was constituted by clones $\mathrm{C}_{3}$-FCA and $\mathrm{Ne}-\mathrm{SJ}$, which showed an average oil yield of $0.43 \%$. The average essential oil yield observed for the first and second group surpass in $67.7 \%$ and $10.8 \%$, respectively, the percentages of oil reported by Weglarz and Geszprych [33], whereas the essential oil content observed in the third and fourth group was in the range reported by these authors $(0.30-1.30 \%)$.

Finally, the number of branches per plant ranged from 94 (Me-TS) to 123 ( $\mathrm{C}_{1}$-FCA); however, no significant differences were observed among the twelve evaluated clones.

Principal component analysis (PCA) showed that 73.1\% of the total variability is explained by the first factorial plane (PC1 and PC2). At the level of the first axis (PC1), which explains $42.2 \%$ of the total variability, the variables with greater weight were the leave dry weight, fresh weight of the second harvest, internode length, and essential oil content, whereas the second axis (PC2) explains 30.9\% of total variability, and the variables with greater inertia are the stem dry weight, leaf/stem ratio, and leaf area (Figure 1).

3.2. Potrero de Garay Essay. With regard to the length of the longest branch, measured three months after planting, clone $\mathrm{Ne}-\mathrm{SJ}$ differed significantly from the other clones, showing the longest branch length mean value, while no differences were observed among the 11 remaining clones (whose branch length ranged between 26.90 and $38.16 \mathrm{~cm}$ ) (Table 4). Considering the same variable, measured one year after sowing, the clones Me-Mza, Me-TS, and VL-TS differed from the other clones by their shorter length $(22.12 \mathrm{~cm}$ on average), and the clones $\mathrm{C}_{8}-\mathrm{FCA}(41.88 \mathrm{~cm})$ and $\mathrm{C}_{3}-\mathrm{FCA}$ $(47.10 \mathrm{~cm})$ were distinguished by their greater length, while no differences were observed between the remaining clones, with an average branch length of $33.79 \mathrm{~cm}$.

Regarding the fresh weight yield of the first harvest, clones $\mathrm{C}_{8}$-FCA, Ne-SJ, Cm-Mza, and NB-TS were those that stood out for their higher production of fresh biomass, with an average fresh weight of $61.34 \mathrm{~g} \mathrm{plant}^{-1}$, while the clones $\mathrm{Me}-\mathrm{Mza}$ and Me-TS differed from the rest of the clones by their poor performance in fresh matter (on average $8.73 \mathrm{~g}$ plant $^{-1}$ ), followed by the clone Cd-Mza with a fresh biomass yield of 21.35 g plant $^{-1}$. In relation to dry weight, clones $\mathrm{C}_{8}$ FCA, Ne-SJ, Cm-Mza, and NB-TS showed dry biomass yields significantly superior from those observed in the remaining clones, followed by clones $\mathrm{C}_{3}-\mathrm{FCA}, \mathrm{C}_{2}$-FCA, $\mathrm{C}_{1}$-FCA, VLTS, Cr-Mza, and Cd-Mza, with an average dry matter yield of $15.21 \mathrm{~g} \mathrm{plant}^{-1}$. Being the clones Me-Mza and Me-TS those showed the lowest yield in dry weight (Table 4).

The higher production of fresh and dry biomass observed in clones $\mathrm{C}_{8}$-FCA, Ne-SJ, Cm-Mza and NB-TS can be associated with the largest number of branches per plant (more than 60 branches per plant), with a longer branch $\left(\mathrm{C}_{8}\right.$-FCA and $\left.\mathrm{Ne}-\mathrm{SJ}\right)$ and greater leaf area (cm Mza and NBTS) (Table 4). The low yields observed in the first harvest for fresh and dry weight, lower than those values reported by Droushiotis and Della [32] and Weglarz and Geszprych [33], can be attributed to the dehydration suffered by the plants during the week before the harvest, being the clones Me-Mza and $\mathrm{Me}$-TS the clones that most resented the lack of water.

In the second harvest, clones Ne-SJ, NS-TS, Cm-Mza, $\mathrm{C}_{3}$-FCA, and $\mathrm{C}_{8}$-FCA showed a significantly superior yield, both in fresh as in dry biomass, with an average fresh weight of $152.97 \mathrm{~g} \mathrm{plant}^{-1}$ and an average dry weight of $58.17 \mathrm{~g}$ plant $^{-1}$. Clones $\mathrm{C}_{1}-\mathrm{FCA}, \mathrm{C}_{2}-\mathrm{FCA}, \mathrm{Cr}-\mathrm{Mza}$, and Cd-Mza showed average yields in fresh and dry matter of $89.31 \mathrm{~g}$ plant $^{-1}$, and $38.02 \mathrm{~g} \mathrm{plant}^{-1}$ respectively; while the clones Me-Mza and Me-TS were those with the lowest yield both in fresh weight $\left(25.70 \mathrm{~g} \mathrm{plant}^{-1}\right)$ as in dry weight $(11.26 \mathrm{~g}$ plant $\left.{ }^{-1}\right)$, as they were in the first harvest, followed by the clone VL-TS.

As regards the percentage of water that is lost during the drying process, significant differences were observed between the clones both in the first as in the second harvest. In both harvests, the clones Me-Mza and Me-TS showed the lowest water content (and the highest percentage of fibers) (Table 4). At this point, it is important to note that in the week preceding the first harvest, Potrero de Garay field was exposed to water stress, so the percentage of water lost during the drying process was lower than in La Consulta and Capilla de los Remedios. For this same reason, the percentage of fibers of the different clones, measured in the first harvest, was overestimated; however, it was possible to differentiate the oregano clones based on these variables. It is reasonable 
to assume that a high fiber content (equivalent to less water loss) results in a higher dry weight yield. Even though clones Me-Mza and Me-TS had higher fiber content, their biomass production was so low that they fail to align their yields with those clones that have higher percentages of water.

In addition, significant differences were found among the clones in terms of the dry weight of the leaves and the stems and leaf/stem ratio (Table 4), being this latter variable of major economic importance when estimating amount of production since it is the leaves that are used for consumption. The clones Ne-SJ, NB-TS, and Cm-Mza were those that showed the greatest values for leaf/stem ratio, coinciding with the greatest number of branches, longest branch, and greatest leaf area (Table 4).

Concerning the content of essential oils, the clones MeMza and Me-TS showed an essential oil yield significantly higher than the rest of the clones, with an average of $3.87 \%$ of oil, followed by the clones $\mathrm{C}_{2}$-FCA, $\mathrm{C}_{1}$-FCA, Cd-Mza, Cr-Mza, $\mathrm{C}_{8}-\mathrm{FCA}$, and $\mathrm{C}_{3}$-FCA, which showed an average oil content of $1.29 \%$ and the clones VL-TS, NB-TS, Cm$\mathrm{Mza}$ and Ne-SJ (clones with the lowest performance in oils, producing on average $0.48 \%$ ). The essential oil yield observed for the clones Me-Mza and Me-TS was similar the one reported for Origanum dubium (3.30 to $5.85 \%$ ) [32]. These percentages were three times higher than those reported by Weglarz \& Geszprych [33] and 32.5\% higher than the yield observed in Turkish oregano (Origanum onites) [36], one of the species of greater content of essential oils.

The principal component analysis (PCA) showed that $82.6 \%$ of the total variability was explained by the first factorial plane (CP1 and $\mathrm{CP} 2$ ). On the level of $\mathrm{CP} 1$, component that by itself explains $63.8 \%$ of the total variability, the variables with higher weight were the dry weight of leaf, the fresh weight measured at the second harvest, and the content of essential oils, while, at the level of CP2, the variables with greater inertia were leaf area and length of the longest branch (measured at 400 days after planting) (Figure 2).

3.3. Capilla De Los Remedios Essay. Regarding to the length of the longest branch, measured 85 days after seeding, the clones VL-TS, Cm-Mza, NB-TS, C 8 -FCA, $\mathrm{C}_{3}-\mathrm{FCA}$, and $\mathrm{Ne}-\mathrm{SJ}$ differed significantly from the rest, recording the lowest values for this variable (range 14.03 and $21.22 \mathrm{~cm}$ ) (Table 5). When this variable was determined 400 days after sowing, $\mathrm{Ne}-\mathrm{SJ}$ and VL-TS differed from the other clones for its smaller branch length $(15.34 \mathrm{~cm}$ on average), while Cd-Mza and Cr-Mza were stood out for their greater length $(40.16 \mathrm{~cm})$. No differences were observed between the remaining genotypes, whose average branch length was $27.44 \mathrm{~cm}$ (Table 5).

With regard to fresh weight yield of the first harvest, two significantly different groups were distinguished. The clones $\mathrm{C}_{8}$-FCA, Cm-Mza, NB-TS, $\mathrm{C}_{3}$-FCA, and Ne-SJ comprise the higher group, with an average production of fresh biomass of 228.77 g plant $^{-1}$, exceeding $75.14 \%$ the group of lower values for the variable formed by the seven remaining clones, which had an average yield of fresh weight of $130.62 \mathrm{~g} \mathrm{plant}^{-1}$. The

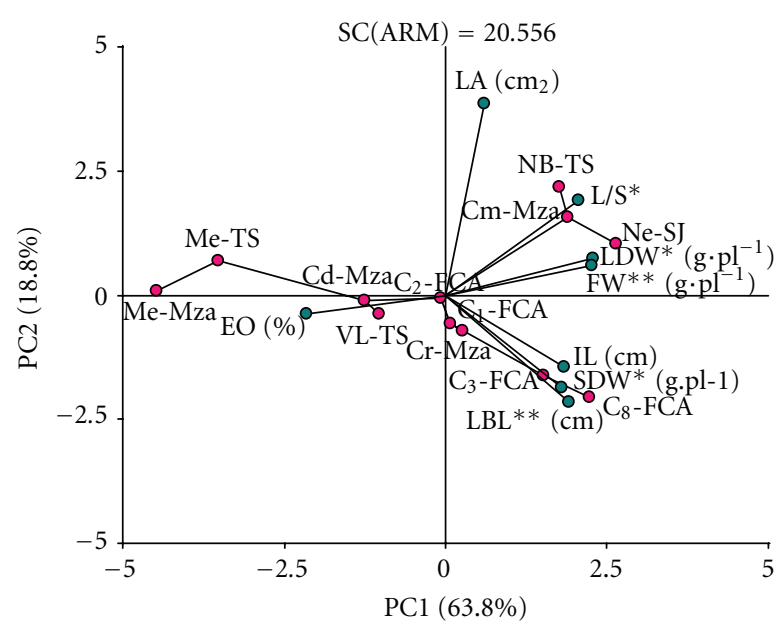

Figure 2: Biplot plane formed by the two first principal components (CP1 and CP2), where the dots represent the 12 clones of oregano evaluated and the vectors, quantitative characteristics measured in Potrero de Garay (Córdoba). $\mathrm{C}_{1}$-FCA: clone $1 \mathrm{C}_{2}$ FCA: clone 2, $\mathrm{C}_{3}$-FCA: clone 3, $\mathrm{C}_{8}$-FCA: clone 8; Me-Mza: clone "Mendocino," Cm-Mza: clone "Compacto," Cd-Mza: clone "Cordobés," Cr-Mza: clone "Criollo," Me-TS: clone "Mendocino," NB-TS: clone "Negrito B," VL-TS: clone "Verde Limón," Ne-SJ: clone "Negrito," LBL: longest branch length, IL: internode length, LA: leaf area, FW: fresh weight, LDW: leave dry weight, SDW: stem dry weight, L/S: ratio LDW/SDW, EO: essential oil content, * measured at 1 st harvest (three month after sowing), ${ }^{* *}$ measured at 2 nd harvest (one year after sowing).

same trend was observed in relation to dry weight, where the clones Cm-Mza, NB-TS, $\mathrm{C}_{8}$-FCA and Ne-SJ differed significantly from the rest by its higher values which averaged $69.75 \mathrm{~g} \mathrm{plant}^{-1}$ (Table 5). As in the essays of La Consulta and Potrero de Garay, clones with higher production of fresh and dry biomass are generally characterized by the presence of a greater number of branches per plant (more than 70 branches per plant), shorter internodes, and greater leaf area. Once again, the observed values for the variables fresh weight and dry weight are within the range reported by Droushiotis and Della [32] and Weglarz and Geszprych [33].

Although in the second harvest the clones differed from one to another both in fresh as dry weight (Table 5), due to the strong predation caused by ants, the recorded yields did not reflect the real potential of each genotype. Although all the clones were targeted by these insects, Ne-SJ, VL-TS, MeTS, $\mathrm{C}_{8}$-FCA, and $\mathrm{C}_{3}$-FCA were the most affected, being $\mathrm{Ne}$ SJ the clone that showed the most important performance reduction for fresh and dry biomass $\left(50.01 \mathrm{~g} \mathrm{plant}^{-1}\right.$ and $16.75 \mathrm{~g} \mathrm{plant}^{-1}$, resp.). Taking into account the agronomic performance observed for the same clone (Ne-SJ) both in the essays conducted in La Consulta and Potrero de Garay as in the first harvest of this essay, it can be assumed that in normal conditions (without predation) the yield of this clone would be far higher. Furthermore, it is reasonable to assume that without ants, the second harvest would be maintained the trend observed in the first one for all the clones. Regardless of the insect damage, the clones VL-TS 
and Me-TS were usually the lowest performing group both in fresh as in dry biomass yield, following the same trend observed in La Consulta and Potrero de Garay. The clones NB-TS, Cm-Mza, $\mathrm{C}_{3}$-FCA, and $\mathrm{C}_{8}$-FCA (which were the top performers in the first harvest) and the clone Me-Mza (low performance in the first harvest) did not differ significantly from clones $\mathrm{C}_{1}-\mathrm{FCA}, \mathrm{C}_{2}-\mathrm{FCA}$, and Cd-Mza, with an average fresh weight yield of $106.69 \mathrm{~g} \mathrm{plant}^{-1}$ while the clone Cr-Mza had a biomass yield significantly higher than the rest of the clones, with an average fresh weight of $162.36 \mathrm{~g} \mathrm{plant}^{-1}$. In terms of dry weight, the clones VL-TS, Ne-SJ, Me-TS, $\mathrm{C}_{8}-$ FCA, and $\mathrm{C}_{3}$-FCA had an average yield of $24.34 \mathrm{~g} \mathrm{plant}^{-1}$; the clones Me-Mza, Cm-Mza, $\mathrm{C}_{1}-\mathrm{FCA}$, NB-TS, Cd-Mza, and $\mathrm{C}_{2}$-FCA yielded an average of $50.21 \mathrm{~g} \mathrm{plant}^{-1}$ while Cr-Mza was significantly higher than the rest with a fresh biomass production averaged $77.14 \mathrm{~g} \mathrm{plant}^{-1}$ (Table 5).

Respecting to the percentage of water lost during the drying process, significant differences were seen among the clones both in the first as in the second harvest. In the first harvest, $\mathrm{C}_{8}$-FCA differed significantly from the rest of the clones, with a water content exceeding $5.71 \%$ of the 11 remaining clones and being also the genotype with the lowest fiber content (Table 5). In the second harvest, the clone with highest water content was $\mathrm{Ne}-\mathrm{SJ}(65.46 \%)$, a value that was on average $7.58 \%$ higher than that observed for clones. Regarding the fiber content in the second harvest, the clones Cd-Mza, $\mathrm{C}_{2}$-FCA, Cr-Mza, Me-TS, VL-TS, and Me-Mza had the highest value for this variable, containing average of $45.54 \%$ of fiber (Table 5). As already noted above it can be assumed that, at the same fresh weight yield, a higher fiber content is equivalent to a higher dry matter yield.

Regarding the leaves and stems dry weight and leaf/stem ratio, significant differences were also observed between genotypes. The clones mainly characterized by shorter internodes, high number of branches, and the greater leaf area (clones NB-TS and Cm-Mza) and the low stems weight (clone Me-TS) were those who showed the highest values for leaf/stem ratio (Table 5).

Concerning the content of essential oils, Me-Mza and Me-TS differed significantly from the rest of clones, with an average essential oil content of $2.15 \%$, while no differences were observed among the 10 remaining clones (which oil content ranged from $0.33 \%$ to $1.11 \%$ ). According to Kokkini [37], based on performance of essential oils, it is possible to categorize the different genotypes of oregano into three groups: (a) those producing less than $0.05 \%$ ("poor" in oils), (b) those with essential oil content between 0.05 and $2 \%$, and (c) those with an essential oil yield over $2 \%$ ("rich" in oil). Both in this essay as in those conducted in La Consulta and Potrero de Garay, clones of oregano belonging to the three groups were distinguished. The clones called "Mendocino" (Me-Mza and Me-TS) belong to the rich-oil group, with a performance that in the three locations exceeds $2 \%$, while the clones called "Compacto" (Cm-Mza) and "Negritos" (NBTS and Ne-SJ) belong to the group poor-oil group. These results are consistent with those observed by De Mastro [38]. Franz \& Novak [35] propose to use differential production of oregano based on the essential oil yield, destinating for use as dried herb those materials having 1 to $3 \%$ of oil, and

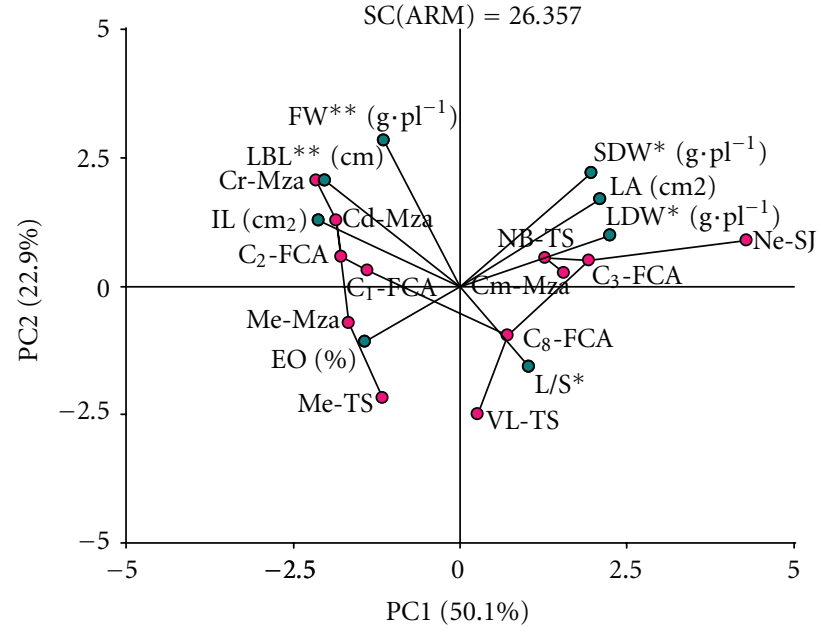

FIGURE 3: Biplot plane formed by the two first principal components (CP1 and $\mathrm{CP} 2$ ), where the dots represent the 12 clones of oregano evaluated and the vectors, quantitative characteristics measured in Capilla de los Remedios (Córdoba). $\mathrm{C}_{1}$-FCA: clone $1 \mathrm{C}_{2}$-FCA: clone 2, $\mathrm{C}_{3}$-FCA: clone 3, $\mathrm{C}_{8}$-FCA: clone 8; Me-Mza: clone "Mendocino," Cm-Mza: clone "Compacto," Cd-Mza: clone "Cordobés," Cr-Mza: clone "Criollo," Me-TS: clone "Mendocino," NB-TS: clone "Negrito B," VL-TS: clone "Verde Limón,” Ne-SJ: clone "Negrito," LBL: longest branch length, IL: internode length, LA: leaf area, FW: fresh weight, LDW: leave dry weight, SDW: stem dry weight, L/S: ratio LDW/SDW, EO: essential oil content, * measured at 1st harvest (three month after sowing); ** measured at 2 nd harvest (one year after sowing).

for essences production those clones containing levels of oil exceeding 3\%. Oregano production intended for obtaining essential oils becomes more important if we consider that these essences and/or its components represent a potentially important source of pharmacologically active compounds [39] or agrochemicals (as herbicides) [40]. Particularly, it has been tested that the essential oil of oregano has a strong antioxidant activity in foods with high-fat content and friedsalted peanuts $[41,42]$.

The principal component analysis (PCA) showed that $73 \%$ of the total variability is explained by the first factorial plane formed by the two first principal components. On the level of CP1, that by itself explains $50.1 \%$ of the total variability, the more discriminating variables were leaf dry weight, leaf area, dry weight of stems, the length of internodes and the essential oil content, while on the level of CP2 (which accounts for $22.9 \%$ of the total variability observed) were fresh weight measured in the second harvest, leaf/stem ratio, and the length of the longest branch. The PCA showed that all 12 clones of oregano evaluated tend to cluster in a manner similar to those observed in La Consulta and Potrero de Garay (Figure 3).

With regard to generalized procrustes analysis (GPA), combining the information obtained for quantitative traits in clones of oregano grown in the three locations, the eigenvalues indicate that the first two axes explain $100 \%$ of the variability. Figure 4 shows the consensus configuration between the rankings generated by the principal components 
TABle 6: Taxonomic identification of 12 clones of oregano from the main cultivation areas.

\begin{tabular}{|c|c|c|c|c|}
\hline Clone & Common name & Origin & Herbarium number & Taxa \\
\hline Me-TS & "Mendocino" & Córdoba (Valle de Traslasierras) & Torres 0901 (CORD) & Origanum $x$ majoricum Cambessedes \\
\hline VL-TS & "Verde Limón" & Córdoba (Valle de Traslasierras) & Torres 0909 (CORD) & Origanum vulgare ssp. hirtum (Link) Iestwaart \\
\hline NB-TS & “Negrito" & Córdoba (Valle de Traslasierras) & Torres $0910(\mathrm{CORD})$ & Origanum vulgare ssp. vulgare \\
\hline $\mathrm{Ne}-\mathrm{SJ}$ & "Negrito" & San Juan (Santa Lucía) & Torres 0911 (CORD) & Origanum vulgare ssp. vulgare \\
\hline Me-Mza & "Mendocino" & Mendoza (La Consulta) & Torres $0902(\mathrm{CORD})$ & Origanum $x$ majoricum Cambessedes \\
\hline Cm-Mza & “Compacto" & Mendoza (La Consulta) & Torres 0903 (CORD) & Origanum vulgare ssp. vulgare \\
\hline Cd-Mza & "Cordobés" & Mendoza (La Consulta) & Torres 0905 (CORD) & Origanum vulgare ssp. hirtum (Link) Iestwaart \\
\hline $\mathrm{Cr}-\mathrm{Mza}$ & "Criollo" & Mendoza (La Consulta) & Torres 0904 (CORD) & Origanum vulgare ssp. hirtum (Link) Iestwaart \\
\hline $\mathrm{C}_{1}$-FCA & - & Córdoba (FCA-UNC) & Torres $0912(\mathrm{CORD})$ & Origanum vulgare ssp. hirtum (Link) Iestwaart \\
\hline $\mathrm{C}_{2}-\mathrm{FCA}$ & "Criollo" & Córdoba (FCA-UNC & Torres 0906 (CORD) & Origanum vulgare ssp. hirtum (Link) Iestwaart \\
\hline $\mathrm{C}_{3}-\mathrm{FCA}$ & - & Córdoba (FCA-UNC) & Torres 0907 (CORD) & Origanum vulgare ssp. hirtum (Link) Iestwaart \\
\hline $\mathrm{C}_{8}$-FCA & 一 & Córdoba (FCA-UNC) & Torres 0908 (CORD) & Origanum vulgare ssp. hirtum (Link) Iestwaart \\
\hline
\end{tabular}

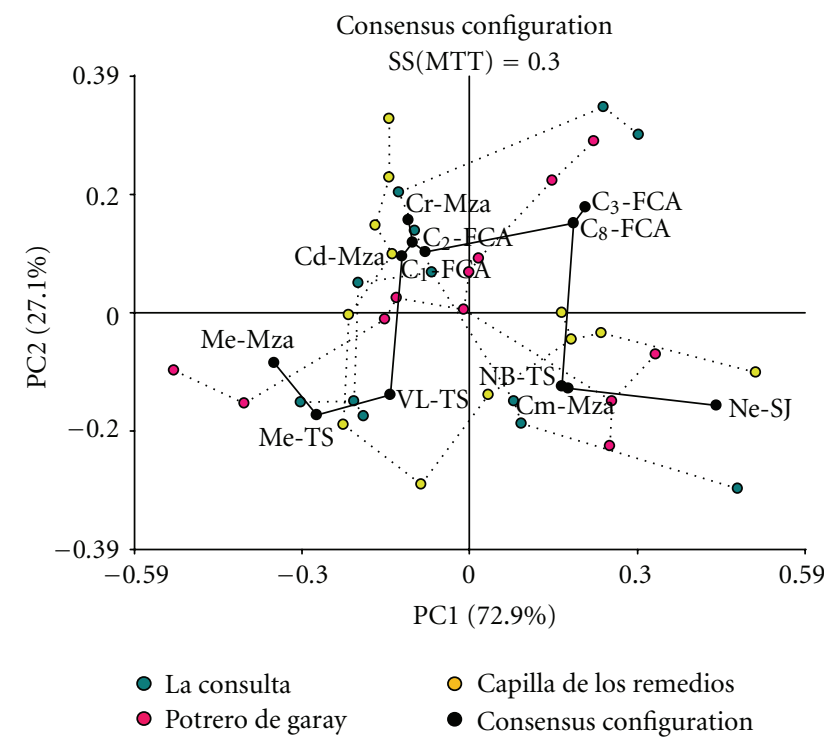

Figure 4: Arrangement the 12 clones of oregano on the plane formed by first two axes of a PGA (with minimum tree trail), considering quantitative characteristics evaluated at the three locations of cultivation. $\mathrm{C}_{1}$-FCA: clone $1, \mathrm{C}_{2}$-FCA: clone 2, $\mathrm{C}_{3}$ FCA: clone 3, $\mathrm{C}_{8}$-FCA: clone 8, Me-Mza: clone "Mendocino," CmMza: clone "Compacto," Cd-Mza: clone "Cordobés," Cr-Mza: clone "Criollo," Me-TS: clone "Mendocino," NB-TS: clone "Negrito B," VL-TS: clone "Verde Limón," Ne-SJ: clone "Negrito."

of the quantitative characters measured in La Consulta, Potrero de Garay, and Capilla de los Remedios. From the ratio between the consensus and the total sum of squares, it can be concluded that there is a $77.3 \%$ of consensus between the configurations produced by the quantitative traits measured in each one of the growing locations. From the GPA it can be said that, regardless of their agronomic performance, the 12 clones of oregano evaluated tend to be clustered in a similar way in the three locations where the essays were conducted; moreover four groups of oregano can be clearly distinguished (Figure 4).
3.4. Taxonomic Identification of the Evaluated Clones. The taxonomic identification of the material evaluated at field was conducted using the keys of Iestwaart [29], Xifreda [2], and Rouquaud \& Videla [3]. In accordance with those keys, the classification of the different clones of oregano was largely based on floral characteristics such as shape of the calyx, the length of the bracts, the length of the staminal filaments, and the color of bracts and flowers. From the observations made, it was determined that 10 of the 12 clones of oregano evaluated belong to the genus Origanum, section Origanum, and two of them are hybrids (Table 6).

In our country, Rouquaud \& Videla [3] reported the existence of "oregano" belonging to Origanum vulgare ssp. vulgare and the hybrid Origanum $x$ majoricum, while the subspecies Origanum vulgare ssp hirtum is reported for the first in this paper. In addition to the taxa mentioned, specimens belonging to the species Origanum dictamnus and Origanum vulgare ssp. viride [2], Origanum vulgare ssp. virens [3], Origanum majorana and the hybrid Origanum $x$ applii $[2,3]$ were described in the country. Since the "oregano" includes a group of cross-pollinated species, the genetic variability within and between them is very high [32]. Thus the variability observed between clones belonging to the same species can be attributed to genetic variation originated by recombination processes inherent in all species whose members reproduce sexually [43].

\section{Conclusions}

The quantitative traits analyzed allowed the characterization of the 12 clones of oregano studied, establishing four clearly distinguishable groups. Regardless of the cultivation site, most discriminate quantitative traits were essential oil content, internodes length, longest branch length (400 days), fresh weight (2nd harvest), leave dry weight, stem dry weight, ratio $\mathrm{H} / \mathrm{T}$, and foliar area. The 12 evaluated clones can be clustered as follow: (Group 1) clones Me-TS and Me-Mza; (Group 2) clones Cd-Mza, Cr-Mza, $\mathrm{C}_{1}$-FCA, and $\mathrm{C}_{2}-\mathrm{FCA}$; (Group 3) clones Cm-Mza, NB-TS, and Ne-SJ (Group 4) clones $\mathrm{C}_{3}$-FCA and $\mathrm{C}_{8}$-FCA. The clone VL-TS is a particular 
case since if it shares characteristic of different groups such as long branches and long internodes (group 2) and low essential oil content (less than 1\%) (group 4).

Otherwise, the12 clones were identified taxonomically, confirming that two of these clones correspond to the hybrid Origanum $x$ majoricum Cambessedes, three of the clones belong to the species Origanum vulgare ssp. vulgare and the remaining 7 clones belong to the species Origanum vulgare ssp. hirtum (Link) Iestwaart. Regardless of the growing location, clones were clustered in the same way, and these groups are consistent with their taxonomic determination. Differences observed among the clones pertaining to the same species can be attributed to the variability generated in the recombination processes.

\section{Acknowledgments}

The authors are indebted to the Secretaría de Ciencia $y$ Tecnología-Universidad Nacional de Córdoba (SECyT-UNC) for the Ph. D. fellowship of Lorena E. Torres. They also want to thank Silvina Panonto, Juan Bastías, Hernán Bagatello and Eduardo Garcia for their invaluable contribution to this work.

\section{References}

[1] A. Azizi, Genetic, chemical and agro-morphological evaluation of the medicinal plant Origanum vulgare L. for marker assisted improvement of pharmaceutical quality [Ph.D. thesis], Justus Liebig University Giessen, Institute of Crop Science and Plant Breeding I, Giessen, Germany, 2010.

[2] C. Xifreda, "Sobre oréganos cultivados en Argentina," Kurtziana, vol. 16, pp. 133-148, 1983.

[3] E. Rouquaud and M. E. Videla, "Oréganos de Mendoza (Argentina)," Revista de la Facultad de Ciencias Agrarias, vol. 32, no. 2, pp. 23-32, 2000.

[4] A. Di Fabio, "El cultivo y su efecto sobre la calidad en orégano," Agosto 2010, http://www.caempa.com.ar/.

[5] O. Arizio, A. Curioni, G. Sanchez Vallduvi, and M. García, "El cultivo de orégano (Origanum sp)," in Plantas Aromáticas y Madicinales: Labiadas, A. Curioni and O. Arizio, Eds., pp. 5792, Hemisferio Sur, 2006.

[6] A. E. Lenardis, A. Gil, and C. Morvillo, "Capítulo 4.3: Orégano," in Cultivos Industriales, pp. 509-544, Facultad de Agronomía-UBA, Buenos Aires, Argentina, 2006.

[7] M. Korukluoglu, O. Gurbuz, Y. Sahan, A. Yigit, O. Kacar, and R. Rouseff, "Chemical characterization and antifungal activity of Origanum onites L. essential oils and extracts," Journal of Food Safety, vol. 29, no. 1, pp. 144-161, 2009.

[8] J. S. Dambolena, M. P. Zunino, E. I. Lucini et al., "Total phenolic content, radical scavenging properties, and essential oil composition of Origanum species from different populations," Journal of Agricultural and Food Chemistry, vol. 58, no. 2, pp. 1115-1120, 2010.

[9] O. Koksal, E. Gunes, O. Orkan Ozer, and M. Ozden, "Analysis of effective factors on information sources at Turkish oregano farms," African Journal of Agricultural Research, vol. 5, no. 2, pp. 142-149, 2010.

[10] G. Farías, O. Brutti, R. Grau et al., "Morphological, yielding and quality descriptors of four clones of Origanum spp. (Lamiaceae) from the Argentine Littoral region Germplasm bank," Industrial Crops and Products, vol. 32, no. 3, pp. 472480, 2010.

[11] A. Di Fabio, "Perspectivas de producción de plantas aromáticas y medicinales en Latinoamérica," in Conferencia: 23rd Congreso Argentino, X Latinoamericano III Iberoamericano de Horticultura, Mendoza, Argentina, 2000.

[12] L. E. Torres, Caracterización y evaluación germoplasma de orégano proveniente de las principales zonas de producción de argentina [Tesis Doctoral], Escuela para Graduados, Facultad de Ciencias Agropecuarias-Universidad Nacional de Córdoba, Córdoba, Argentina, 2011.

[13] D. Suárez, "Orégano en el Valle de Traslasierras. Evaluación de 7 cultivares," Ediciones INTA-Proyecto Frutihortícola, Boletín 9, 2002, Edición Especial, pp. 3-4.

[14] C. Baglio, P. Bauzá, J. Bastías et al., "Resultados red nacional de ensayos de orégano. Parcela La Consulta, San Carlos," in 32nd Congreso Argentino de Horticultura, 1er Simposio Latinoamericano de Floricultura Tropical, Salta, Argentina, Septiembre 2009.

[15] G. Farías and O. Brutti, "Caracterización y evaluación de dos clones de orégano Origanum x applii (Domin) Boros en la provincia de Entre Ríos, Argentina," in 32nd Congreso Argentino de Horticultura, 1er Simposio Latinoamericano de Floricultura Tropical, Salta, Argentina, Septiembre 2009.

[16] L. E. Torres, A. G. Chaves, J. A. Bustos et al., "Comportamiento agronómico de los clones de orégano "Compacto" y "Criollo" sembrados en dos ambientes diferentes," in 32nd Congreso Argentino de Horticultura, ler Simposio Latinoamericano de Floricultura Tropical, Salta, Argentina, Septiembre 2009.

[17] L. E. Torres, A. G. Chaves, P. Brunetti et al., "Variabilidad fenotípica de cuatro clones de orégano cultivados en las localidades La Consulta (Mendoza) y Capilla de los Remedios (Córdoba)," in 2nd Reunión de Biotecnología Aplicada a Plantas Medicinales y Aromáticas, Santa María de Punilla, Córdoba, Argentina, Diciembre 2009.

[18] R. Orell and I. Martínez, "Evaluación de cuatro tipos de orégano (Origanum vulgare L.) en Campo Demostrativo Encalilla-Valles Calchaquíes_Tucumán," in 32nd Congreso Argentino de Horticultura, ler Simposio Internacional de la Frutilla, Simposio de Agroecología, Simposio de Aromáticas, Medicinales y Condimenticias, Rosario, Santa Fe, Argentina, Septiembre-Octubre 2010.

[19] V. M. Lipinski, P. Bauzá, C. Baglio et al., "Efecto del riego por goteo sobre el rendimiento y la calidad del orégano," in 32nd Congreso Argentino de Horticultura, 1er Simposio Latinoamericano de Floricultura Tropical, Salta, Argentina, Septiembre 2009.

[20] V. M. Lipinski, P. Bauzá, C. Baglio et al., "Rendimiento y calidad de orégano cultivado con riego por goteo," in $32 n d$ Congreso Argentino de Horticultura, ler Simposio Internacional de la Frutilla, Simposio de Agroecología, Simposio de Aromáticas, Medicinales y Condimenticias, Rosario, Santa Fe, Argentina, Septiembre-Octubre 2010.

[21] R. C. Moreno, L. E. Mariconda, N. H. Curzel, M. E. Biéc, and E. Albizzatti, "Secadero solar tipo invernadero para orégano en la Patagonia Norte," in 32nd Congreso Argentino de Horticultura, 1er Simposio Latinoamericano de Floricultura Tropical, Salta, Argentina, Septiembre 2009.

[22] C. Baglio, P. Bauzá, J. Bastías, F. Lineaux, D. Locatelli, and C. Amadio, "Efecto de diferentes formas de almacenamiento sobre la calidad de orégano," in 32nd Congreso Argentino de Horticultura, 1er Simposio Latinoamericano de Floricultura Tropical, Salta, Argentina, Septiembre 2009. 
[23] R. C. Moreno, L. E. Mariconda, M. Berzins, and E. Albizzatti, "Secado solar de orégano en época otoñal en la Patagonia Norte," in 32nd Congreso Argentino de Horticultura, 1er Simposio Internacional de la Frutilla, Simposio de Agroecología, Simposio de Aromáticas, Medicinales y Condimenticias, Rosario, Santa Fe, Argentina, Septiembre-Octubre 2010.

[24] L. Mariconda, F. Bagolín, M. Biéc, N. Curzel, and R. Moreno, "Evaluación de color y aroma de orégano deshidratado en secadero solar tipo invernadero en la Patagonia Norte," in 33rd congreso Argentino de Horticultura, 1er Simposio Internacional de la Frutilla, Simposio de Agroecología, Simposio de Aromáticas, Medicinales y Condimenticias, Rosario, Santa Fe, Argentina, Septiembre-Octubre 2010.

[25] M. Mirábile, E. Peral, L. Vignoni, P. Bauzá, and C. Baglio, "Diferentes formas de acondicionamiento de orégano fresco para su conservación," in 33rd Congreso Argentino de Horticultura, 1er Simposio Internacional de la Frutilla, Simposio de Agroecología, Simposio de Aromáticas, Medicinales y Condimenticias, Rosario, Santa Fe, Argentina, Septiembre-Octubre 2010.

[26] M. S. Ré, E. Artiñano, C. Henning et al., "Caracterización de cuatro poblaciones de especies aromáticas como fuente de timol y carvacrol," in 33rd Congreso Argentino de Horticultura, 1er Simposio Latinoamericano de Floricultura Tropical, Salta, Argentina, Septiembre 2009.

[27] M. D. Gonzáles, C. Luis, and P. Lanzellotti, "Estudio químico de Origanum vulgare ssp viridulum," in 33rd Congreso Argentino de Horticultura, ler Simposio Internacional de la Frutilla, Simposio de Agroecología, Simposio de Aromáticas, Medicinales y Condimenticias, Rosario, Santa Fe, Argentina, Septiembre-Octubre 2010.

[28] L. E. Torres, A. G. Chaves, G. Barboza et al., "Evaluation of the agronomic performance and taxonomic characterization of four clones of oregano (Origanum sp.)," Molecular Medicinal Chemistry, vol. 21, pp. 91-93, 2010.

[29] J. H. Ietswaart, A taxonomic revision of the genus Origanum (Labiatae) [Tesis Doctoral], Leiden University Press, Leiden, The Netherlands, 1980.

[30] Infostat, "Infostat versión 2009," Grupo Infostat, Facultad de Ciencias Agropecuarias, Universidad Nacional de Córdoba, Córdoba, Argentina, 2009, http://www.infostat.com.ar/.

[31] J. Di Rienzo, W. Guzmán, and F. Casanoves, "D.G.C., Test de Comparación de Medias. InfoStat Versión 1.1/Profesional," Grupo InfoStat, Facultad de Ciencias Agropecuarias, Universidad Nacional de Córdoba, Córdoba, Argentina, 2001, http://www.infostat.com.ar/.

[32] D. Droushiotis and A. Della, "Genetic resources of medicinal and aromatic plants in Cyprus with emphasis on the selection, evaluation and management of Origanum dubium," in Proceedings of the Working Group on Medicinal and Aromatic Plants Meeting, D. Baricevic, J. Bernáth, L. Maggioni, and E. Lipman, Eds., pp. 39-41, Gozd Martuljek, Slovenia, September 2002.

[33] Z. Weglarz and A. Geszprych, "The status of medicinal and aromatic plants in Poland," in Proceedings of the Working Group on Medicinal and Aromatic Plants Meeting, D. Baricevic, J. Bernáth, L. Maggioni, and E. Lipman, Eds., pp. 96-101, Gozd Martuljek, Slovenia, September 2002.

[34] C. Leto and A. Salamone, "Bio-agronomical behaviour in Sicilian Origanum ecotypes," in Proceedings of the IPGRI International Workshop on Oregano, S. Padulosi, Ed., pp. 6873, CIHEAM, Valenzano, Bari, Italy, 1997.

[35] C. Franz and J. Novak, "Part IV—cultivation and breeding: breeding of Oregano," in Oregano: The Genera Origanum and Lippia, S. E. Kintzios, Ed., pp. 163-174, Taylor \& Francis, 2002.
[36] A. O. Sari and B. Oguz, "Activities on medicinal and aromatic plants at the Aegean Agricultural Research Institute," in Proceedings of the Working Group on Medicinal and Aromatic Plants Meeting, D. Baricevic, J. Bernáth, L. Maggioni, and E. Lipman, Eds., pp. 121-127, Gozd Martuljek, Slovenia, September 2002.

[37] S. Kokkini, "Taxonomy, diversity and distribution of Origanum species," in Proceedings of the IPGRI International Workshop on Oregano, S. Padulosi, Ed., pp. 2-12, CIHEAM, Valenzano, Bari, Italy, 1997.

[38] G. De Mastro, "Crop domestication and variability within accessions of Origanum genus," in Proceedings of the IPGRI International Workshop on Oregano, S. Padulosi, Ed., pp. 3448, CIHEAM, Valenzano, Bari, Italy, 1997.

[39] J. A. Zygadlo and H. R. Juliani Jr., "Bioactivity of essential oil components," Current Topics in Phytochemistry, vol. 3, pp. 203-214, 2000.

[40] M. P. Zunino and J. A. Zygadlo, "Effect of monoterpenes on lipid oxidation in maize," Planta, vol. 219, no. 2, pp. 303-309, 2004.

[41] R. H. Olmedo, V. Nepote, M. G. Mestrallet, and N. R. Grosso, "Effect of the essential oil addition on the oxidative stability of fried-salted peanuts," International Journal of Food Science and Technology, vol. 43, no. 11, pp. 1935-1944, 2008.

[42] R. H. Olmedo, C. Asensio, V. Nepote, M. G. Mestrallet, and N. R. Grosso, "Chemical and sensory stability of fried-salted peanuts flavored with oregano essential oil and olive oil," Journal of the Science of Food and Agriculture, vol. 89, no. 12, pp. 2128-2136, 2009.

[43] J. Sustar-Vozlic, "Genetic variability of native populations of oregano in Slovenia," in Proceedings of the Working Group on Medicinal and Aromatic Plants Meeting, D. Baricevic, J. Bernáth, L. Maggioni, and E. Lipman, Eds., pp. 147-149, Gozd Martuljek, Slovenia, September 2002. 


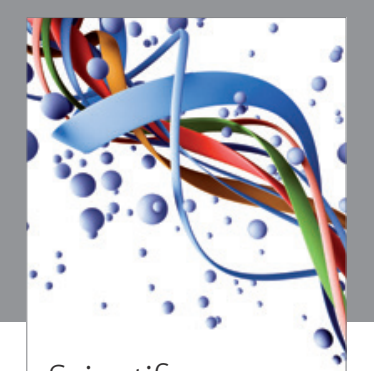

Scientifica
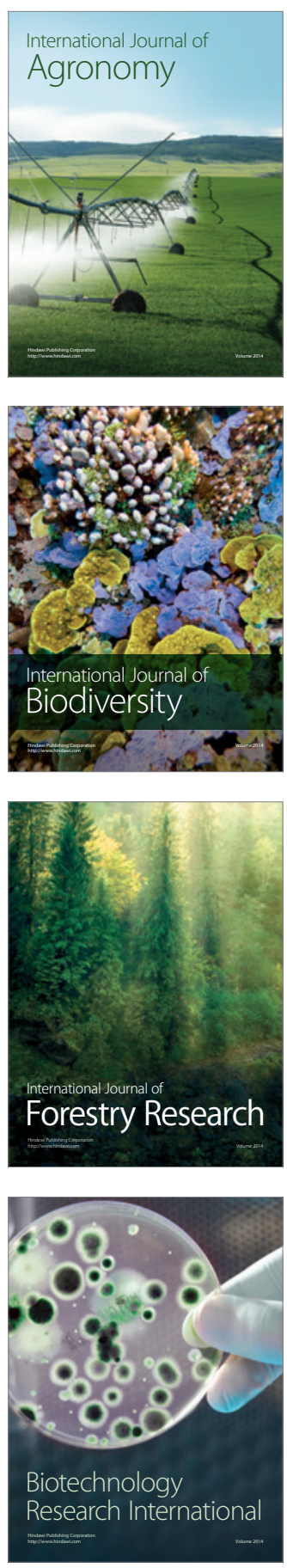
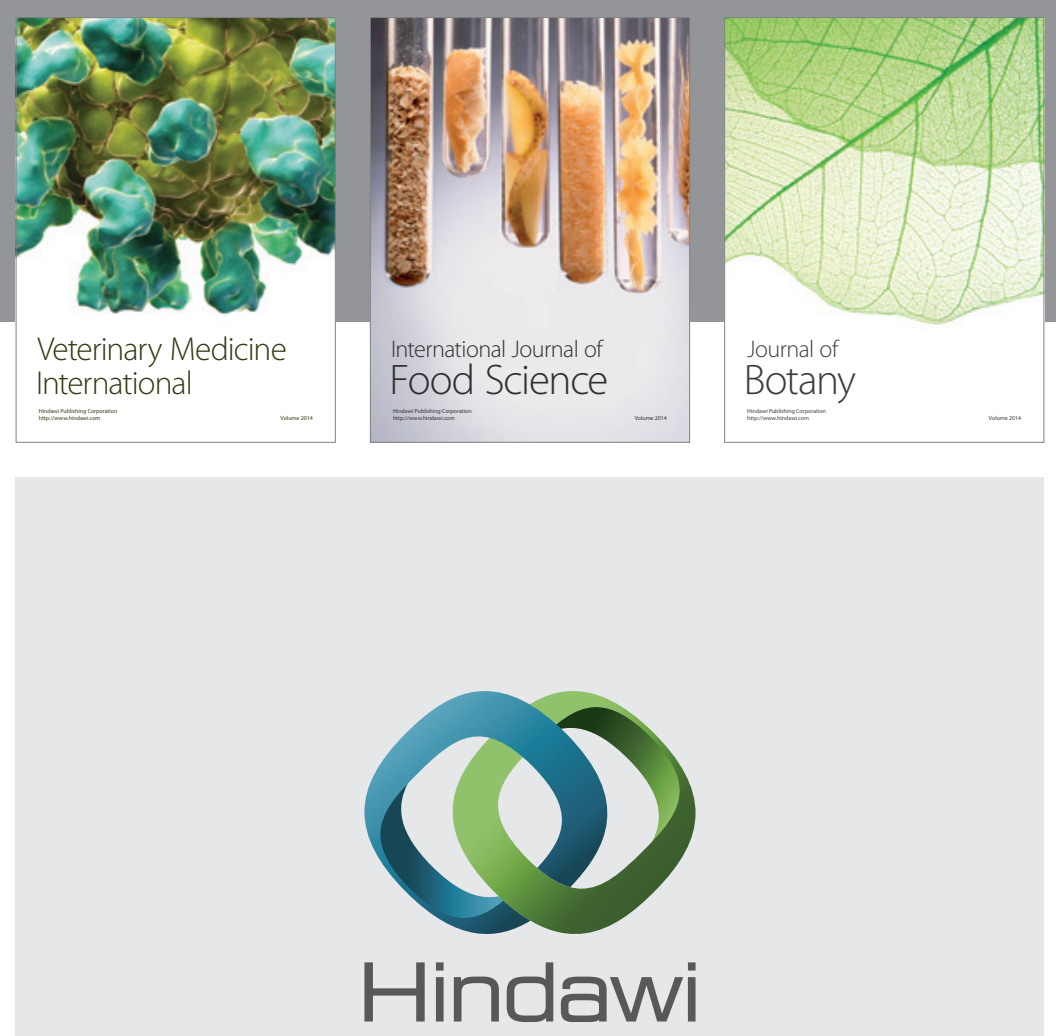

Submit your manuscripts at

http://www.hindawi.com
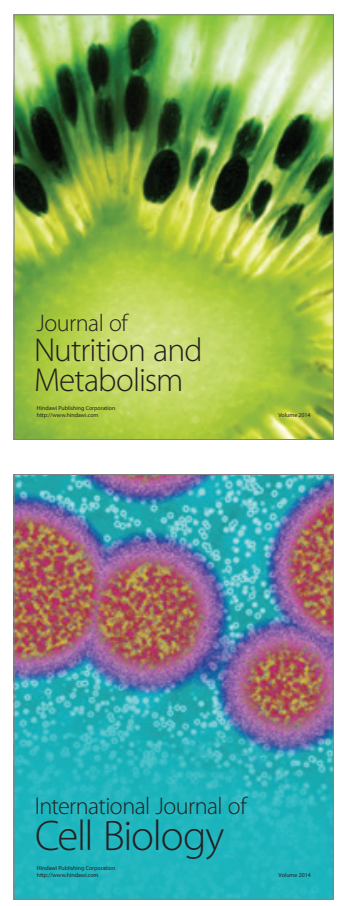
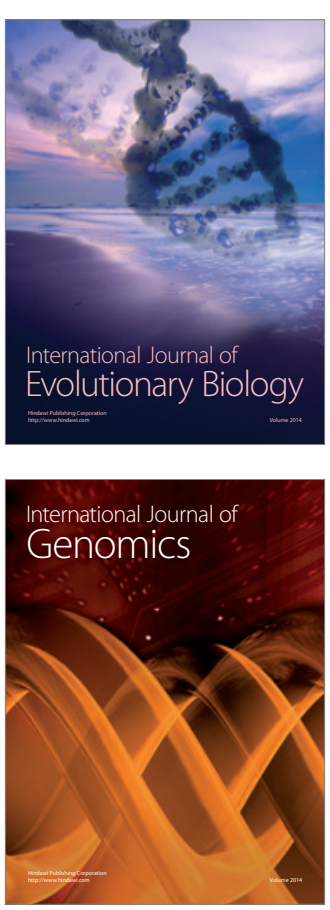
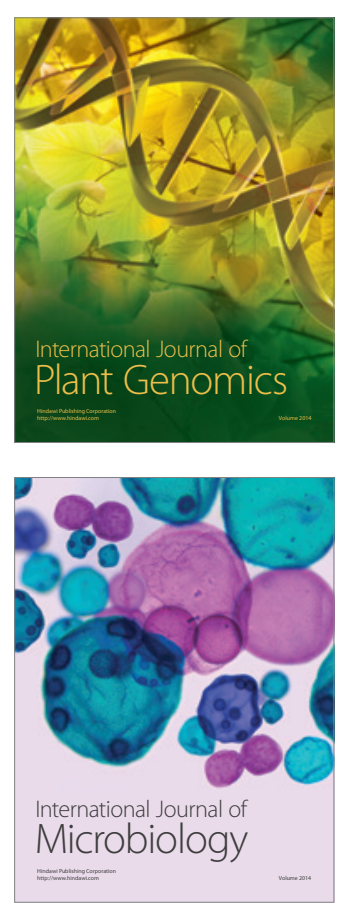

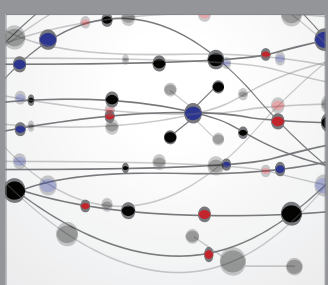

The Scientific World Journal
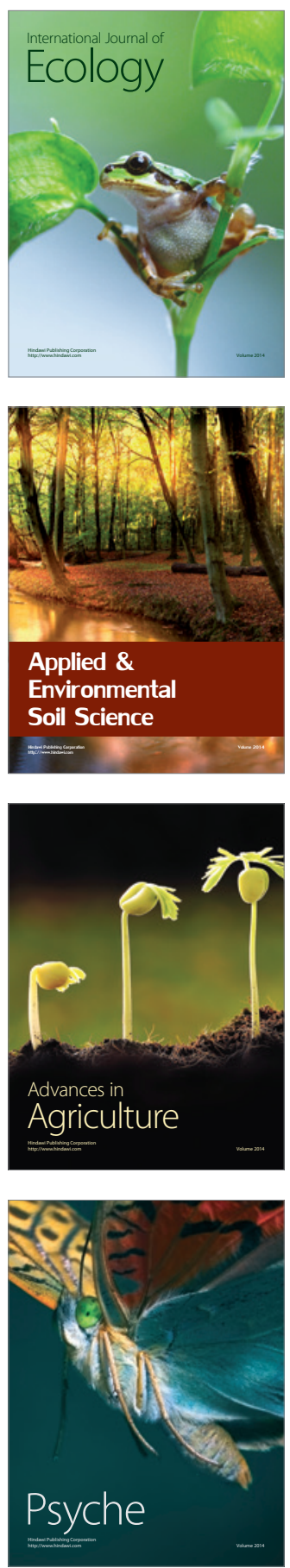